\title{
Estimating the Pragmatic Language Abilities in Indian Adolescents between 10 and 16 Years of Age: Using Contextually Flooded Visual Scenes
}

\author{
Larisa Vaz ${ }^{\mathrm{a}, \mathrm{b}}$, Sudhin Karuppali ${ }^{\mathrm{a}, \mathrm{b}}$ \\ ${ }^{a}$ Department of Audiology and Speech Language Pathology, Kasturba Medical College, Mangalore, India \\ ${ }^{b}$ Manipal Academy of Higher Education, Manipal, Karnataka, India
}

Correspondence: Sudhin Karuppali, PhD Department of Audiology and Speech-Language Pathology, Kasturba Medical College, Light House Hill Road, Mangalore 575001, India

Tel: +91-9844-807634

Fax +91-824-2428183

E-mail: sudhin.karuppali@manipal.edu

Received: May 4, 2019

Revised: July 31, 2019

Accepted: July 31, 2019

We are grateful and thank the school authority for their cooperation to conduct our study and making it a good success. We thank the Dean, Kasturba Medical College, Manipal Academy of Higher Education, Mangalore, for supporting us to conduct such a study.

\begin{abstract}
Objectives: The assessment of pragmatic language in adolescents mainly focuses on using academic and other communicative contexts that they are largely exposed to. Considering the lesser focus laid on aspects of pragmatic language in India, the current study aims to profile the context-related pragmatic language abilities in typically developing adolescents using ingenious visual-based scenes. Methods: The participants were 10- to 16-year-old allocated into six age groups with 1-year intervals. The targeted context-related parameters were physical context-setting (PCS), physical context-event (PCE), audience relationship (AR), audience number (AN), audience mood (AM), and context total (CT). The study was carried out in three phases. Phase I included the development of the stimuli (stimuli preparation, content validation, and pilot study); Phase II involved the task administration; while, Phase III involved the data and statistical analysis. Results: The results have been discussed based on the age-wise comparisons of the total scores received in PCS, PCE, AR, AN, AM, and $\mathrm{CT}$. The results of the Kruskal-Wallis test indicated an overall good level of significance $(p<.05)$ across the 6 groups for all six parameters. Though Mann Whitney Tests indicated a poor level of significance $(p>.05)$ between certain groups across certain parameters, a good level of significance $(p<.05)$ was obtained when viewing the groups from a cognitive perspective (10-11, 12-14, and 15 years). Conclusion: This study delivers a novel tool in understanding pragmatic developmental trends in Indian children, laying new paths towards the assessment of adolescents with language disorders.
\end{abstract}

Keywords: Adolescence, Assessment, Context, Picture, Pragmatics
Pragmatics, which refers to the utilisation of language that is socially suitable to its context (Ciccia \& Turkstra, 2002), blends semantics, morpho-syntax, and the overall language understanding along with spoken expression to make communication effective. An effective use of pragmatic language requires an assortment of abilities, along with the capability to deliver satisfactory and acceptable information to listeners; initiating, maintaining, and terminating a conversation exchange while conserving a logical and coherent sequence; partaking the problem of discussion with a companion; and also monitoring the accomplishment of self-spo- ken productions while interacting in a social environment (Ciccia \& Turkstra, 2002). Success in the usage of pragmatic skills is an instrumental element of the older child's experience, partly due to the greater interactive communication abilities that turn into a powerful aspect of personal status (Adler \& Adler, 1998; Ciccia \& Turkstra, 2002).

The assessment of pragmatic language in adolescents does majorly focus on academic and other communicative contexts that they are generally exposed to. Given the complex nature of pragmatic language behaviours, the evaluation of these skills can be 
challenging, leaving several clinicians to be dependent on nonstandardized and observational methods that can be difficult for determining service admissibility (Olswang, Coggins, \& Timler, 2001; Young, Diehl, Morris, Hyman, \& Bennetto, 2005). There has been an increased focus on the development of valid standardized tests (Wiig \& Secord, 1989), and using more descriptive and naturalistic assessment procedures (Damico, 1993). Tasks such as structured interviews (Selman, Beardslee, Schultz, Krupa, \& Podorefsky, 1986), generation of figurative expressions (Karuppali \& Bhat, 2014; Nelsen \& Rosenbaum, 1972), production of spoken and written discourse (Berman \& Verhoeven, 2002; Karuppali, Babu, \& Bhat, 2017; Vieiro \& Garcia-Madruga, 1997), and story narration (Appose \& Karuppali, 2018) have repeatedly indicated older adolescents display better performances compared to younger ones.

Apart from the numerous standardized language tests designed to assess language skills in adolescents (Dewart \& Summers, 1995; Gilliam \& Miller, 2006; Hammill, Brown, Larsen, \& Lee Wiederholt, 2007; Hammill \& Larsen, 2009; Hammill \& Newcomer, 2008; Phelps-Terasaki \& Phelps-Gunn, 1992; Wiig, Semel, \& Secord, 2013), there also do exist questionnaires, checklists, and profiles (Andersen-Wood \& Smith, 2001; Fey, 1986; Miller, 1981; Muir, Tanner, \& France, 1992; Prutting \& Kittchner, 1987; Retherford, 1987; Warner, 2002). Though there are many tests targeted to assess adolescent pragmatic language, only a few are available for the Indian population. One of the earliest tests tapping into the language deficits encountered by adolescents is the Linguistic Profile Test (LPT) originally designed by Suchithra and Karanth (2007) in the Kannada language, which contains the elicitation of a discourse sample through picture description, story narration and an interview. Several unpublished variants of LPT are available in other Indian languages such as Hindi, Malayalam, Telugu, Nepali, and Konkani. The Manipal Manual of Adolescent Language Assessment developed by Karuppali and Bhat (2015) focussed on the assessment of higher linguistic aspects (figurative language), which is often considered to be a crucial part of pragmatic function. With a dearth of studies focussing on the pragmatic language aspects in India, there is an ever-growing demand to develop culturally and linguistically sensitive language tests. Using the available western standardized tests has time and again proved their poor applicability in an Indian scenario. However, adapting certain aspects of western language tests may help structure a tool for the Indian setting. Tests such as the Test of Pragmatic Language (TOPL) do mainly use picture-based stimuli tapping into a wide array of pragmatic acts depicting contextual based scenarios that are encountered by adolescents. Along these lines, the current study aims to profile the pragmatic language abilities in typically developing Indian adolescents between 10 and 16 years of age using ingenious visual-based scenes.

\section{METHODS}

As the present study focused on profiling pragmatic language abilities in English, the participants were selected from English medium schools in Mangalore, that followed the Karnataka Secondary Education Examination Board. The participants were selected using simple random convenient sampling (lottery method). An aggregate of 150 typically developing school-going children between 10 and 16 years of age participated in the study. The participants were distributed into 6 groups depending on their age varying with 1 -year age intervals. Table 1 displays the distribution of the participants allocated for each age group.

School teachers, who play a major role in determining the academic potential of the child, were given a questionnaire to select suitable participants. Screening for speech, language, hearing, and cognitive issues were done using a standardized checklist (Karuppali \& Bhat, 2014). Participants who fit into the selection criteria were considered for the study.

\section{Procedure}

The present study was carried out in three phases. The Phase I included the development of the stimuli; Phase II involved the task

Table 1. Distribution of the participants under each age group ( $N=150)$

\begin{tabular}{lcc}
\hline Group & Age $(\mathrm{yr} ; \mathrm{mo})$ & Number of participants \\
\hline I & $10-10 ; 11$ & 25 \\
II & $11-11 ; 11$ & 25 \\
III & $12-12 ; 11$ & 25 \\
IV & $13-13 ; 11$ & 25 \\
V & $14-14 ; 11$ & 25 \\
VI & $15-15 ; 11$ & 25 \\
\hline
\end{tabular}


administration; while Phase III involved the data and statistical analysis.

\section{Phase I: Development of the stimuli}

This phase included the development of the stimuli that targeted tapping into the pragmatic language abilities in adolescents. This phase comprised of three stages: stimuli preparation, content validation, and pilot study.

In the stimuli preparation stage, tasks were compiled from the existing literature, available western-standardized language tools, and other sources (the Internet). The materials which primarily comprised of the assessment of pragmatic language skills in children and adolescents using visual-based scenes were considered at this level. The TOPL, developed by Phelps-Terasaki and PhelpsGunn (1992), was used to help develop the visual-based scenes and the pragmatic (physical context) model of assessment. In addition, suitable visual scenes were considered from the Internet source (Google images). A total of 54 visual scenes were identified. These pictures were further shortlisted by considering the co-curriculum and vocabulary of the target population. The pictures were selected based on their portrayal of pragmatic contexts. Consequently, 29 visual scenes were shortlisted and given to a professional artist so as to alter the visual scenes to culturally suit the Indian context in order to consider the novelty of the stimuli. Care was taken to ensure that the painted visual scenes incorporated realistic themes (using appropriate colours) with minute details so as to achieve the objective of the study. Following this, each of the 29 visual scenes was scanned (Canon PIXMA MG2470), so as to convert the stimuli into a high-resolution visual image (.jpeg format). Following the scanning, each of the pictures was inserted and ordered in a presentation program (Microsoft PowerPoint).

For the purpose of the study, context-related parameters were included physical context-setting (PCS), physical context-event (PCE), audience relationship (AR), audience number (AN), audience mood (AM), and the context total (CT). The context parameter referred to the environment in which a conversation is taking place and the variety of audiences to which the conversation is directed. The PCS depicts the place where the conversation takes place (e.g., library, classroom, park, etc.); whereas the PCE refers to the visualisation of the entire scene, where the event itself becomes a context for the communication exchange. The AR represents the types of communication relationships that are present in the conversation; wherein the conversation may be depicted between two or more individuals. The AM refers to the general feel of the conversation and is closely tied to the relationship between participants; whereas AN refers to the number of individuals present in the entire scene. The sum score of PCS, PCE, AR, AN, and AM is the CT. Standard keywords for the various pragmatic parameters were decided and scoring was formulated accordingly, so as to aid in the objectivity of scoring. An appropriate scoring system was devised for the evaluation of the participants using the designed stimuli. Scoring was assigned under each visual scene for each parameter and its corresponding components. A score of 1 was assigned for a correct response; while a score of 0 was assigned for an incorrect response. This scoring system was similar to the one followed by Phelps-Terasaki and Phelps-Gunn (1992).

The stimuli validation formed the second stage, which was performed by two expert speech-language pathologists having a minimum experience of 5 years in the area of language development. The validation process happened at different time periods during the stimuli preparation. The first content validation happened during the stimulus preparation stage, wherein the experts were required to shortlist the 54 visual scenes to 29 in number. This was achieved by scrutinizing the pragmatic scenes to ascertain if it incorporated the pragmatic contexts. This scrutiny was done using a checklist, wherein the judges were required to indicate each pragmatic act (in terms of the context) that was portrayed by each visual scene. The suggestions by the experts were noted, and the necessary actions were taken. The suggestions mostly included the elimination of certain visual scenes, modification of visual scenes considering its unsuitability in an Indian setting, and considerations to alter visual scenes due to the complexity of the task.

The final stage comprised of conducting a pilot study on 30 participants ( 5 participants $\times 6$ groups) who were recruited using a simple random sampling method (lottery). The guidelines followed on the presentation of the stimuli are mentioned in Phase II. Following the pilot study, a total of 18 visual scenes were included for the final data collection. The pragmatic context-based parameters, its components, and the corresponding assigned scores for each of the 18 finalised visual scenes have been mentioned in Appendix 1. 


\section{Phase II: Task administration}

For the administration of the developed task, each of the participants was seated comfortably on a chair in a silent room located within the school premises. Following the collection of the demographic details (name, date of birth, gender, standard, and school), each stimulus was presented in a systematic order using a laptop that was placed at a distance of 25-30 inches away from the participant, so as to maintain a distance that was visually comfortable for the participant. A common probe question ("What is happening in the picture?") was used to elicit the responses for every visual scene in the stimuli. The examiner further probed in ("Do you have anything else to say about the picture?") to elicit the desired response. The recording of the language output was done using a digital voice recorder (Sony ICD-PX240 4 GB Voice Recorder). Each participant took approximately 15-20 minutes to complete the task.

\section{Phase III: Data and statistical analysis}

The elicited language samples were subjected to offline analysis. The data analysis comprised of scoring the responses by the participants on each of the 18 visual scenes that were presented. During the analysis, the examiner carefully listened to the recorded audio samples, thereby simultaneously assigning scores for each of the visual scenes for each participant. The analysis primarily targeted all the context-related parameters (PCS, PCE, AR, AN, AM, and CT) for each visual scene. All data were entered into the excel sheet. The time taken for the analysis of each language sample was around 20-30 minutes.

Statistical analysis was done using SPSS version 16 (SPSS Inc., Chicago, IL, USA). Descriptive analysis was done to obtain the mean and standard deviation (SD) of the groups for all the parameters. The independent variable was the age of the participants. Dependent variables were the six context-related parameters. The Shapiro-Wilk test of normality was done to check for normality indicating the need for non-parametric tests. While the KruskalWallis test was used to determine the level of significance across the age groups; the Mann-Whitney test was done to determine the level of significance between the age groups.

\section{RESULTS}

\section{Physical Context-Setting}

The results of the descriptive statistics indicate groups I and II to exhibit near similar scores, with a three-fold increase in the scores of the participants of group III. Though group IV scored lesser than its preceding group (group III), there was a further increment in the scores of group V and VI. The minimum score achieved in this section was 0 , while the maximum score was 18 . However, no groups attained the maximum score of 18. Figure 1 depicts the group-wise total scores received for the PCS parameter. The results of the Kruskal-Wallis test showed a statistically significant difference across the groups, $\chi^{2}(5)=74.84, p<.05$, with group I attaining a mean rank PCS score of 36.84, group II (35.42), group III (90.38), group IV (71.84), group V (108.78), and group VI (109.74) at 95\% confidence intervals (CIs) 1.77-3.50, 1.52-3.51, 5.829.85, 4.77-6.66, 8.02-10.13, and 7.99-10.72 for the groups I, II, III, $\mathrm{IV}, \mathrm{V}$, and VI, respectively. As observed from the group-wise comparisons, the Mann-Whitney test results found significant differences between the age groups II-III $(p<.05)$ and IV-V $(p<.05)$, while the age groups I-II $(p=.06)$, III-IV $(p=.09)$, and V-VI $(p=.57)$ received a poor level of significance.

\section{Physical Context-Event}

The results of the descriptive statistics indicate group I to have scored the least among all the groups. A minimal increment in the scores was observed in group II, with group III exhibiting a subsequent decline in scores. However, the scores of groups IV, V, and VI had plateaued at the score of 17 . The minimum score achieved

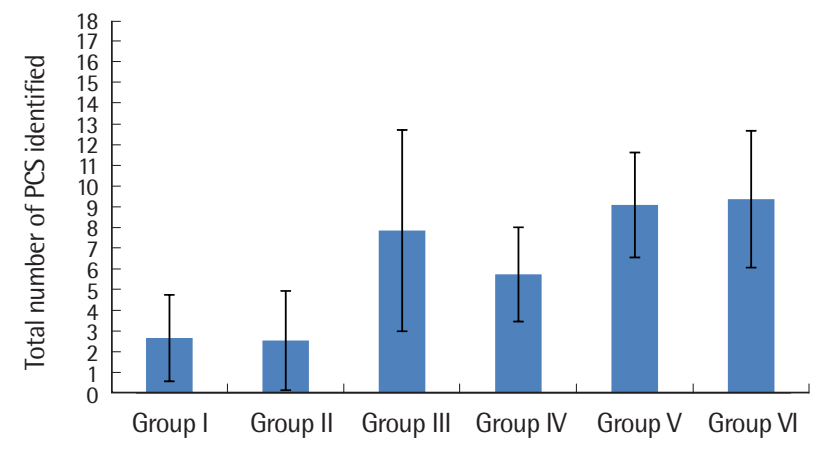

Figure 1. Mean and SD of the total number of physical context-setting (PCS) identified by each group. 
in this section was 7, while the maximum score was 20 . No groups did attain the maximum score of 21 . Figure 2 depicts the groupwise total scores received for the PCE parameter.

The results of the Kruskal-Wallis test showed a statistically significant difference across the groups, $\chi^{2}(5)=26.09, p<.05$, with group I attaining a mean rank PCE score of 47.34, group II (74.38), group III (61.70), group IV (95.12), group V (85.56), and group VI (88.90) at 95\% CIs 15.25-17.14, 16.84-17.95, 15.68-17.51, 17.44-18.39, 17.58-18.09, and 17.51-18.24 for the groups I, II, III, IV, V, and VI, respectively. As observed from the group-wise comparisons, the Mann-Whitney test results found significant differences between age groups I-II $(p<.05)$ and III-IV $(p<.05)$, while the age groups IIIII $(p=.25), \operatorname{IV}-\mathrm{V}(p=.16)$, and V-VI $(p=.67)$ received a poor level of significance.

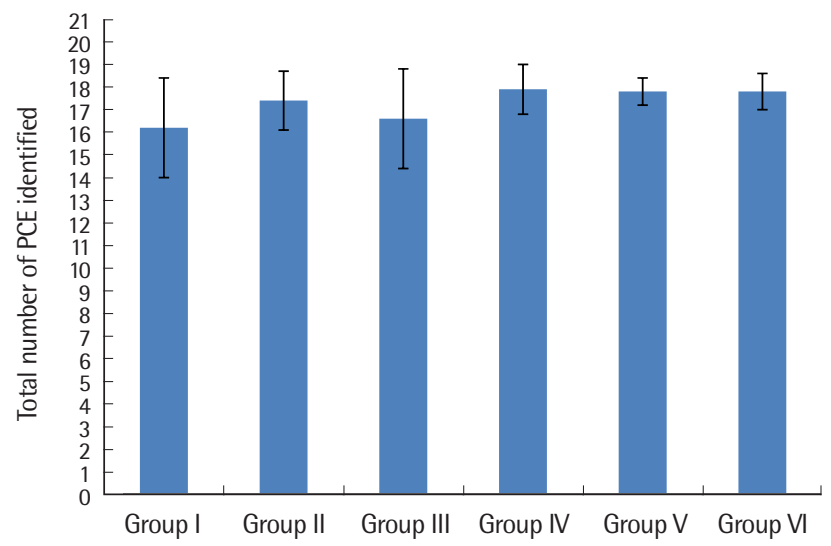

Figure 2. Mean and SD of the total number of physical context-event (PCE) identified by each group.

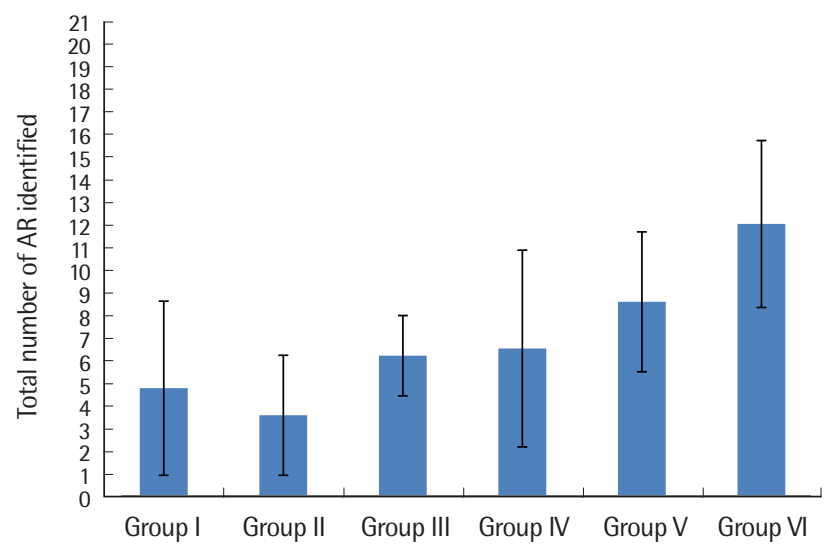

Figure 3. Mean and SD of the total number of audience relationship (AR) identified by each group.

\section{Audience Relationship}

The results of the descriptive statistics indicate a steady increase in the scores across all groups except for group II, wherein a subtle decline in scores was evident. Group III and IV exhibited near similar scores, with a subsequent increasing trend seen across group $\mathrm{V}$ and VI. The minimum score achieved in this section was 0 , while the maximum score was 18 . However, no groups attained the maximum score of 21 . Figure 3 depicts the group-wise total scores received for the AR parameter.

The results of the Kruskal-Wallis test demonstrated a statistically significant difference across the groups, $\chi^{2}(5)=60.30, p<.05$, with group I attaining a mean rank AR score of 51.86, group II (39.50), group III (73.42), group IV (70.12), group V (95.20), and group VI (122.90) at 95\% CIs 3.20-6.39, 2.50-4.96, 5.50-6.97, 4.758.36, 7.07-9.64, and 10.52-13.63 for the groups I, II, III, IV, V, and VI, respectively. As observed from the group-wise comparisons, the Mann-Whitney test results found significant differences between age groups II-III $(p<.05), \operatorname{IV}-\mathrm{V}(p<.05)$, and V-VI $(p<.05)$, while the age groups I-II $(p=.35)$ and III-IV $(p=.57)$ showed a poor level of significance.

\section{Audience Number}

The results of the descriptive analysis indicate least scores obtained by group I with group II, III, IV, V, and VI showing a plateau-like trend in the participant's scores. The minimum score achieved in this section was 25 , while the maximum score was 48 . However, no groups attained the maximum score of 48 . Figure 4 depicts the group-wise total scores received for the AN parameter.

The results of the Kruskal-Wallis test indicated a statistical sig-

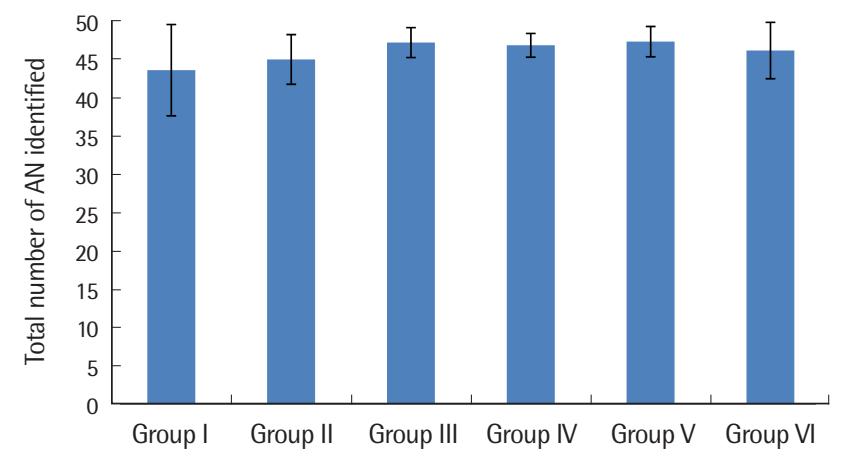

Figure 4. Mean and SD of the total number of audience number (AN) identified by each group. 
nificant difference across the groups, $\chi^{2}(5)=19.335, p<.05$, with group I attaining a mean rank AN score of 52.20, group II (56.84), group III (90.58), group IV (81.40), group V (90.94), and group VI (81.04) at 95\% CIs 41.10-46.01, 43.61-46.30, 46.35-47.96, 46.1547.44, 46.45-48.10, and 44.60-47.63 for the groups I, II, III, IV, V, and VI, respectively. As observed from the group-wise comparisons using the Mann-Whitney test, the results indicated significant differences between age groups II-III $(p<.05)$, while the I-II ( $p=.57)$, III-IV $(p=.33), \operatorname{IV}-\mathrm{V}(p=.35)$, and V-VI $(p=.44)$ showed a poor level of significance.

\section{Audience Mood}

The results of the descriptive statistics indicate group I to have a score of 5.88. A subtle decrease in the scores of group II was evidenced. Group III and IV exhibited similar scores, with an improving trend in the scores observed for group V and VI. The minimum score achieved in this section was 0 , while the maximum score was 18 . However, no groups attained the maximum score of 21. Figure 5 depicts the group-wise total scores received for the AM parameter.

The results of the Kruskal-Wallis test indicated a statistical significant difference across the groups, $\chi^{2}(5)=52.53, p<.05$, with group I attaining a mean rank AM score of 55.52, group II (41.52), group III (64.54), group IV (76.64), group V (96.70), and group VI (118.08) at 95\% CIs 4.54-7.21, 3.14-5.90, 5.50-7.93, 6.68-9.31, 8.4910.78, and 10.06-12.98 for the groups I, II, III, IV, V, and VI, respectively. As observed from the group-wise comparisons using the Mann-Whitney test, the results revealed a good level of significance

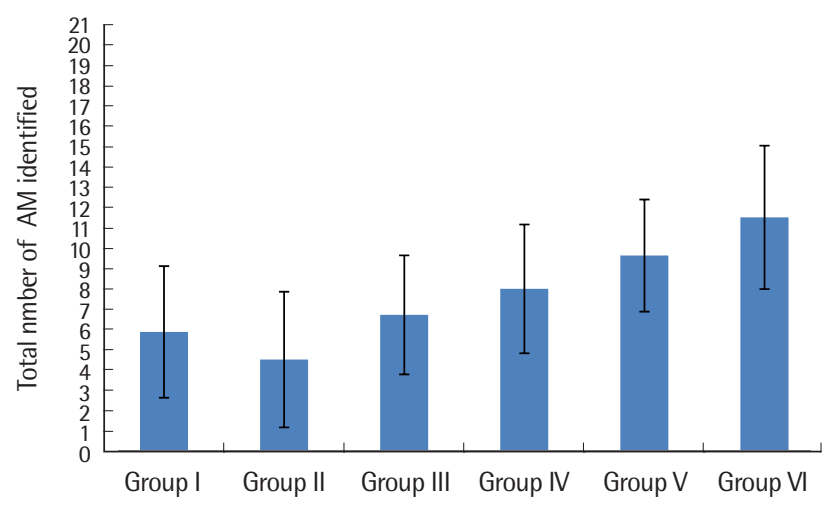

Figure 5. Mean and SD of the total number of audience mood (AM) identified by each group. between age groups II-III $(p<.05)$, IV-V $(p<.05)$ and V-VI $(p<.05)$; while the age groups I-II $(p=.14)$ and III-IV $(p=.30)$ showed a poor level of significance.

\section{Context Total}

The mean and SD for the six groups were 73.08 $\pm 11.14,73.0 \pm$ $7.81,84.56 \pm 7.33,85.0 \pm 7.07,92.24 \pm 5.84$, and 96.96 \pm 11.37 , respectively. The minimum score achieved in this section was 48 , while the maximum score achieved was 112 . However, no groups attained the desired maximum score of 126 . The results of the Kruskal-Wallis test indicated a statistical significant difference across the groups, $\chi^{2}(5)=87.166, p<.05$, with group I attaining a mean rank total content score of 37.30 , group II (32.88), group III (75.18), group IV (76.58), group V (108.72), and group VI (122.34) at 95\% CIs 68.48-77.67, 69.77-76.22, 81.53-87.58, 82.07-87.92, 89.8294.65, and 92.26-101.65 for the groups I, II, III, IV, V, and VI, respectively. The results of Mann-Whitney test revealed a significant difference $(p<.05)$ between groups II-III, IV-V, and V-VI, with a poor level of significance $(p>.05)$ between groups I-II $(p=.946)$ and III-IV $(p=.930)$.

\section{DISCUSSION \& CONCLUSION}

\section{Physical Context-Setting}

The 10- and 11-year-old groups achieved near parallel scores (mean score $=2.5$ ) which were significantly lower compared to the subsequent 12-year-old group. The maximum scores obtained by the 10- and 11-year-old groups were 7 and 8, respectively. However, none of the participants of both groups could achieve the maximum score of 18 for the PCS parameter. As observed, the participants of both the groups performed well for the visual scenes 1 (library), 2 (park), and 4 (classroom/school); however, all other scenes were found to be difficult attaining a score of 0 . Similarly, the 12-yearold group performed well for the visual scenes (1, 2, \& 4). In addition, they were able to perceive the settings of 3 (study room), 5 (living room), 7 (playroom), 11 (clock shop), 17 (park), and 18 (restaurant). This increase in scores by the 12 -year-old group indicates their better understanding of other pragmatic settings which were difficult for the 10- and 11-year-old groups. Compared to the 12-yearold group, interestingly, the 13-year-old group obtained a lower 
mean score of 5.7. The lower mean scores of the 13-year-old group could primarily be attributed to the increased difficulty encountered by this group to make concrete decisions (Van Den Bos \& Hertwig, 2017). Considering the type of visual scenes, these participants were not able to perceive visual scenes $3,4,5$, and 18 which were perceived by the 12-year-old group. However, both the subsequent age groups (14- and 15-year-old children) established the utmost mean scores of 9.08 and 9.36, respectively. However, they were not able to perceive the visual scenes of 8 (leisure room), 9 (picture room), 10 (painting room), 12 (hall), 13 (stadium), 14 (living room), and 16 (house). The improvement in the performances in the visual scenes may be attributed to personal factors and experiences that might have influenced the language development with respect to increase in lexical-semantic abilities, use of metalinguistic strategies as one advances through adolescence, acquisition of new vocabulary and better verbal-linguistic abilities. Based on the results of the Kruskal-Wallis test, a good level of significance was obtained, indicating that there was a change in the pragmatic perception and performance of the PCS parameter. This change with age has been reported by Nippold (2000) who suggested language development to have a substantial growth during adolescence which may progress into adulthood. Although language development is subtle and gradual, these changes are considered of great significance during the adolescence period (Nippold, 2000). As observed from the group-wise comparisons using the Mann-Whitney test, the results found significant differences between the age groups 11-12 and 13-14, while the age groups 10-11, 12-13, and 14-15 received a poor level of significance. In order to study this trend, the groups were further studied using age bands (10-11, 12-13, and 1415 as three independent groups). This resulted in obtaining a good level of significance between the three age bands.

\section{Physical Context-Event}

The 10-year-old group attained the lowest scores (mean score $=$ 16.2) which were lower compared to the subsequent 11-year-old group who obtained a mean score of 17.4. The maximum scores obtained by the 10- and 11-year-old groups were 18 and 20, respectively. However, none of the participants of both groups could achieve the maximum score of 21 for the PCE parameter. As observed, the 10-year-old group performed well for most of the visual scenes except for 3 (study room), 8 (leisure room), 12 (hall), and 16 (house) as compared to its subsequent group. The 11-year-old group performed exceptionally well in all the visual scenes except for visual scene 13 (stadium). This increase in score in the 11-year-old group could indicate their better understanding of other pragmatic settings which were difficult for the 10-year-old group. Similarly, the scores of the 12-year-old group witnessed a drop in the mean score (16.6) with the addition of a decline in performance for visual scenes 10 (painting room), 11 (clock shop), and 18 (restaurant) which may be attributed to the lack of attention during the tasks, as all of the three visual scenes were presented during the latter half of the test administration. The age groups of 13, 14, and 15 years performed at par with one another, obtaining mean scores of 17.9, 17.8, and 17.8 respectively. All three groups performed exceptionally well on all the visual scenes. The improvement in the performances in the visual scenes may be attributed to the language development with respect to increasing in lexical-semantic abilities, use of metalinguistic strategies as one advances through adolescence, acquisition of new vocabulary and better verbal-linguistic abilities. Based on the results of the Kruskal-Wallis test, a good level of significance was obtained, indicating that there was a change in the pragmatic perception and performance of the PCE parameter. This developmental change is supported by a study done by Karuppali and Bhat (2014) who studied the figurative language of older adolescents of the age groups 10-16 years, using similes and found an increase in the performance of the adolescents with age; thereby, showing a developmental trend. As observed from the group-wise comparisons, using the Mann-Whitney test revealed significant differences between age groups 10-11 and 12-13, while the age groups 11-12, 13-14, and 14-15 received a poor level of significance. Similarly, while considering the analysis based on age bands of 10 $11,12-13$, and 14-15 years, a poor level of significant difference was found between the three age bands.

\section{Audience Relationship}

The 10-year-old group exhibited better scores (mean score $=4.8)$ compared to the subsequent 11-year-old group who obtained a mean score of 3.6. The maximum scores obtained by the 10 - and 11-year-old groups were 15 and 10, respectively. However, none of the participants of both groups could achieve the maximum score 
of 21 for the AR parameter. As observed, the participants of the 10 -year-old group performed well for the visual scenes 4 (classroom), 6 (clinic), 14 (living room), and 16 (house). Almost all the other visual scenes were found to be difficult where a score of 0 was obtained. The 11-year-old group witnessed a drop in scores while performing well in visual scenes 4 and 6. Similarly, the 12-yearold participants (mean score $=6.24$ ) performed well for the visual scenes 4 and 6; however, in addition, they were able to perceive the visual scene 11 (clock shop). This increase in score in the 12-yearold participants could indicate their better understanding of other pragmatic settings which were difficult for the 10- and 11-year-old groups. Consecutively, the 13-year-old group received a better mean score of 6.56 and performed well for the visual scenes 4, 6, and 11; however, they were able to perceive the visual scene 18 (restaurant). The subsequent 14 -year-old participants received a mean score of 8.63 and performed well for the visual scenes $4,6,11$, and 18. In addition, they were able to perceive the visual scenes 3 (study room), 12 (hall), 14 (living room), and 16 (house). The age group of 15 -year-old received the utmost mean scores of 12.08 and performed well for the visual scenes $3,4,6,11,12,14$, and 16; and also were able perceive the visual scenes 5 (living room), 15 (discussion room), 17 (garden), and 18 (restaurant). However, they were not able to perceive the visual scenes of 1 (library), 2 (park), 7 (playing room), 8 (leisure room), 9 (picture room), 10 (painting room), and 13 (stadium). The improvement in the performances in the visual scenes can be attributed to the language development with respect to increasing in lexical-semantic abilities, use of metalinguistic strategies as one advances through adolescence, acquisition of new vocabulary and better verbal-linguistic abilities. The fact that pragmatic functions differ with respect to the context and audience was established by Perkins, Crisp, and Walshaw (1999). Based on the results of the Kruskal-Wallis test, a good level of significance was obtained, indicating that there was a change in the pragmatic perception and performance of the AR parameter. This change with age has been reported by Nippold (2000) who suggested that language exhibits substantial growth during adolescence and progresses into adulthood. Although language development is subtle and gradual, the changes in the development itself are of great significance during adolescence (Nippold, 2000). As observed from the group-wise comparisons, using the Mann-Whitney test re- vealed significant differences between age groups 11-12, 13-14, and 14-15 years, while the age groups 10-11 and 12-13 years showed a poor level of significance. In order to study this trend, the groups were further studied using age bands (10-11, 12-13, and 14-15 years as three independent groups). This resulted in obtaining a good level of significance between the three age bands.

\section{Audience Number}

The 10- and 11-year-old group achieved near similar scores (mean score $=44$ ) which were significantly lower compared to the subsequent 12-year-old group. The maximum scores obtained by both, the 10- and 11-year-old groups were 48. As observed, the participants of both the groups performed well for the visual scenes 1-18. The age groups of $12,13,14$, and 15 years performed at par with one another. The improvement in the performances in the visual scenes can be attributed to the language development with respect to increasing in lexical-semantic abilities, use of metalinguistic strategies as one advances through adolescence, acquisition of new vocabulary and better verbal-linguistic abilities. Based on the results of the Kruskal-Wallis test, a good level of significance was obtained, indicating that there was a change in the pragmatic perception and performance of the AN parameter. This change with age is supported by Karuppali and Bhat (2014) who studied older adolescents between 10 and 16 years of age, using similes to measure the figurative language. The authors found an increase in the performance of the adolescents with age; thereby, exhibiting a developmental pattern.

As observed from the group-wise comparisons using the MannWhitney test, the results indicated significant differences between age groups 11-12 years, while the age group of 10-11, 12-13, 13-14, and 14-15 years showed a poor level of significance. In order to study this trend, the groups were further studied using age bands (10-11, 12-13, and 14-15 years as three independent groups). This resulted in obtaining a good level of significance between the 1011 and 12-13 age bands; however, a poor significance was obtained between the 12-13 and 14-15 age bands.

\section{Audience Mood}

The 10-year-old group received better scores (mean score $=5.88$ ) and were higher compared to the subsequent 11-year-old group 
who obtained a mean score of 4.52. The maximum scores obtained by both, the 10- and 11-year-old groups was 11; however, none of the participants of both the groups could achieve the maximum score of 21 for the AM parameter. As observed, the participants of the 10-year-old group performed well for the visual scenes 1 (library), 3 (study room), 4 (classroom), 6 (clinic), 14 (living room), 16 (house), and 17 (garden). Almost all the other visual scenes were found to be difficult where a score of 0 was obtained. The 11-yearold group witnessed a drop in scores while performing well in the same visual scenes as the 10-year-old group. Similarly, the 12-yearage group $($ mean score $=6.72$ ) performed well for the visual scenes $1,3,4,6,14,16$, and 17 ; however, in addition, they were able to perceive the visual scene 12 (hall). This increase in score in the 12-yearold participants could indicate their better understanding of other pragmatic visual stimuli which were difficult for the 10- and 11-yearold groups. Consecutively, the 13-year-old participants obtained a better mean score of 8 and performed well for the visual scenes 1 , $3,4,6,12,14,16$, and 17 ; however, in addition, they were able to perceive the visual scenes 13 (stadium) and 18 (restaurant). The subsequent 14 year-old group received a mean score of 9.64 and performed well for the visual scenes $1,3,4,6,12,13,14,16,17$, and 18; however, in addition, they were able to perceive the visual scenes 5 (living room), 7 (playing room), and 11 (clock shop). The 15-yearold group established the maximum mean scores of 11.52 and performed well for all the visual scenes except for scenes 8 (leisure room) and 9 (picture room). The improvement in the performances in the visual scenes can be attributed to the language development with respect to increasing in lexical-semantic abilities, use of metalinguistic strategies as one advances through adolescence, acquisition of new vocabulary and better verbal-linguistic abilities. Based on the results of the Kruskal-Wallis test, a good level of significance was obtained, indicating that there was a change in the pragmatic perception and performance of the AM parameter. This change was also observed and reported by Nippold (2002) who suggested that development of language during adolescence takes place in a substantial manner progressesing into adulthood. Nippold (2000) also reported that the language development during adolescence is subtle and of great significance. As observed from the group-wise comparisons using the Mann-Whitney test, the results revealed a good level of significance between age groups
11-12, 13-14, and 14-15, while the age groups 10-11 and 12-13 showed a poor level of significance. In order to study this trend, the groups were further studied using age bands (10-11, 12-13, and 14-15 years as three independent groups). This resulted in obtaining a good level of significance between the three age bands.

In order to observe the developmental changes perceived under the five contextual parameters (PCS, PCE, AR, AN, and AM), all six groups were further categorised based on the cognitive stages (10-11, 12-14, and 15 years as three independent groups). This resulted in obtaining a good level of significance between the groups, which does indicate that an adolescent's language development depends on their cognitive readiness to advance to higher levels of thought (Berman, 2004). Receiving a good level of significance while considering age bands rather than year-wise observations does indicate adolescent language development (in this case, pragmatic development) can be better perceived only when classifying adolescents into cluster groups (Nippold, 2006). Accomplishment with pragmatic abilities is an instrumental element of the older children's experience, partially as greater interactive communication abilities are a prominent aspect of social status (Adler \& Adler, 1998).

\section{Context Total}

The 10- and 11-year-old groups performed at par with each other, obtaining a mean score of 73 each. The groups received a maximum score of 95 and 86 and a minimum score of 48 and 52, respectively. The 12- and 13-year-old groups obtained similar mean scores 84.5 , while the 14 - and 15-year-old groups received a similar mean score of 94 . These improvements in the performances in the context parameters can be attributed to the language development with respect to increasing in lexical-semantic abilities, acquisition of new vocabulary, and better verbal-linguistic abilities. Developments such as these may be attributed to the extensive reading experience these individuals would have received during their educational years (Reed, 2005), as well as the numerous social experiences established through interactions (Locke \& Bogin, 2006). The development observed across the age groups of the current study does indicate the advancement in the use of metalinguistic strategies, which is a higher linguistic construct, generally taking place during adolescence. The primary development dur- 
ing this period does involve a complex interplay between cognition and pragmatics which is manifested on the basis of the performance in metalinguistic tasks such as the one done in the current study. Considering the socio-cognitive basis towards skill mastery, it is believed that during the period of adolescence, a significant amount of cognitive competency is essential for the mastery in pragmatic skills (Ciccia \& Turkstra, 2002).

Specific areas of skill advancement in older children comprise the occurrence and ultimate blending of reasoning abilities and abstract thought, together with an enhanced executive functioning capabilities (Coleman \& Hendry, 1999; as cited in Ciccia \& Turkstra, 2002). These type of changes permit the individual to develop as a qualitatively enhanced multidimensional thinker that eventually forms the center for improved pragmatic communication efficacy (Ciccia \& Turkstra, 2002). The development of cognitive skills in older children occurs in concurrence with variations in the communication background, including improved contact with various communication partners and better opportunities for participation in extracurricular activities (Ciccia \& Turkstra, 2002). During late childhood (11-12 years of age) Piaget's formal operational stage begins to emerge (Nippold, 2004). A hallmark feature of this developmental period is the ability to employ hypothetical-deductive reasoning (Santrock, 1996). These cognitive advancements are often reflected in the language used for school-related purposes (Nippold, 2004). Along similar lines, Karuppali and Bhat (2014) studied the figurative (similes) language skills of adolescents between 10 and 16 years of age and found an increase in the performance of the adolescents with age, thereby showing a developmental pattern.

For the PCS parameter, it was also observed that none of the participants from any of the age groups were able to perceive the visual scenes of 8 (leisure room), 9 (picture room), 10 (painting room), 12 (hall), 13 (stadium), 14 (living room), and 16 (house). As observed for the AR parameter, none of the participants from any of the age groups were able to perceive the visual scenes of 1 (library), 2 (park), 7 (playing room), 8 (leisure room), 9 (picture room), 10 (painting room), 13 (stadium), and 16 (house). The AM parameter observed poor performances in the visual scenes of 8 (leisure room) and 9 (picture room) where none of the participants from any of the age groups performed, which may be attributed to vari- ous reasons. Firstly, these visual scenes may be considered to be difficult or complex for adolescents, resulting in poor performance. Secondly, the poor performance could be attributed to the exposure and experience participants have received concerning the pragmatic acts evident in the visual scenes. The experience one gets when encountering situations of pragmatic significance do increase with age. Lastly, performance in a task may be influenced by the psychological state of the participant. In the present study, participants were exposed to 18 visual scenes which demanded their verbal response, thereby spending an average of 18-20 minutes throughout the experiment. This could have influenced the participant's level of motivation and attention.

In conclusion, studying pragmatic language measures is crucial to determine the scholastic and communication efficacy of an older child's language competence and performance. The results of the present study may provide a solid foundation in the understanding of pragmatic developmental trends in Indian children, laying new paths towards the assessment of this population with languagerelated disorders. These results will aid in laying customized intervention goals for adolescents who report with language-related difficulties mainly existing in the pragmatic domain. Future studies may be directed to explore the pragmatic abilities using conversational and written tasks as well. It would also be interesting to determine if there are gender-related differences in the display of pragmatic language skills. Furthermore, considering assessing adolescents by extending their age range throughout 19 years of age is also warranted.

\section{REFERENCES}

Adler, P. A., \& Adler, P. (1998). Peer power: preadolescent culture and identity. New Brunswick, NJ: Rutgers University Press.

Andersen-Wood, L., \& Smith, B. R. (2001). Working with pragmatics: a practical guide to promoting communicative confidence. Bicester, UK: Speechmark.

Appose, A., \& Karuppali, S. (2018). Decoding the macrostructural form of oral narratives in typically developing children between 6-11 years of age: using story grammar analysis. Online Journal of Health and Allied Sciences, 17(1), 12. https://www.ojhas.org/issue65/2018-1-12.html

Berman, R., \& Verhoeven, L. (2002). Cross-linguistic perspectives on the de- 
velopment of text-production abilities: speech and writing. Written Language \& Literacy, 5(1), 1-43.

Berman, R. A. (2004). Between emergence and mastery: the long developmental route of language acquisition. In: R. Berman (Ed.), Language development across childhood and adolescence (pp. 9-34). Amsterdam: John Benjamins Publishing.

Ciccia, A. H., \& Turkstra, L. S. (2002). Cohesion, communication burden, and response adequacy in adolescent conversations. Advances in Speech Language Pathology, 4(1), 1-8.

Coleman, J., \& Hendry, L. B. (1999). The nature of adolescence. London, UK: Routledge.

Damico, J. S. (1993). Language assessment in adolescents: addressing critical issues. Language, Speech, and Hearing Services in Schools, 24(1), 29-35.

Dewart, H., \& Summers, S. (1995). The pragmatics profile of communication skills in childhood. Windsor, UK: NFER-Nelson.

Fey, M. L. (1986). Language intervention with young children. Boston, MA: Allyn and Bacon.

Gilliam, J. E., \& Miller, L. (2006). PLSI: Pragmatic Language Skills Inventory. Austin, TX: Pro-ED.

Hammill, D. D., Brown, V. L., Larsen, S. C., \& Lee Wiederholt, J. (2007). TOAL4: Test of Adolescent and Adult Language, fourth edition. Austin, TX: ProED.

Hammill, D. D., \& Larsen, S. C. (2009). TOWL4: Test of Written Language, fourth edition. Austin, TX: Pro-ED.

Hammill, D. D., \& Newcomer, P. L. (2008). Test of Language DevelopmentIntermediate: fourth edition (TOLD-I:4). Austin, TX: Pro-ED.

Karuppali, S., Babu, S., \& Bhat, J. S. (2017). Lexical density and diversity in written language of adolescents between 10-16 years of age. Journal of the Indian Academy of Applied Psychology, 43(2), 316-325.

Karuppali, S., \& Bhat, J. S. (2014). Efficacy of using simile completion tasks as a measure to evaluate the figurative language abilities in adolescents aged between 10-15 years. Nepal Journal of Medical Sciences, 3(2), 110-115.

Karuppali, S., \& Bhat, J. S. (2015). Manipal Manual of Adolescent Language Assessment. Manipal, India: Manipal University Press.

Locke, J. L., \& Bogin, B. (2006). Language and life history: a new perspective on the development and evolution of human language. Behavioral and Brain Sciences, 29(3), 259-280.

Miller, J. F. (1981). Assessing language production in children. Baltimore, MD: University Park Press.

Muir, N., Tanner, P., \& France, J. (1992). Management and treatment tech- niques: a practical approach. In R. Gravell and J. France (Eds.), Speech and communication problems in psychiatry (pp. 244-325). Boston, MA: Springer.

Nelsen, E. A., \& Rosenbaum, E. (1972). Language patterns within the youth subculture: development of slang vocabularies. Merrill-Palmer Quarterly of Behavior and Development, 18(3), 273-285.

Nippold, M. A. (2000). Language development during the adolescent years: aspects of pragmatics, syntax, and semantics. Topics in Language Disorders, 20(2), 15-28.

Nippold, M. A. (2002). Lexical learning in school-age children, adolescents, and adults: a process where language and literacy converge. Journal of child language, 29, 474-8.

Nippold, M. A. (2004). Research on later language development: international perspectives. In R. Berman (Ed.), Language development across childhood and adolescence (pp. 1-8). Philadelphia, PA: John Benjamins Publishing.

Nippold, M. A. (2006). Language development in school-age children, adolescents, and adults. In K. Brown (Ed.), Encyclopedia of language \& linguistics (2nd ed., pp. 368-373). Oxford, UK: Elsevier Science.

Olswang, L. B., Coggins, T. E., \& Timler, G. R. (2001). Outcome measures for school-age children with social communication problems. Topics in Language Disorders, 22(1), 50-73.

Perkins, L., Crisp, J., \& Walshaw, D. (1999). Exploring conversation analysis as an assessment tool for aphasia: the issue of reliability. Aphasiology, 13(45), 259-281.

Phelps-Terasaki, D., \& Phelps-Gunn, T. (1992). TOPL: test of pragmatic language. Austin, TX: Pro-ED.

Prutting, C. A., \& Kittchner, D. M. (1987). A clinical appraisal of the pragmatic aspects of language. Journal of Speech and hearing Disorders, 52(2), 105-119.

Retherford, K. S. (1987). Guide to analysis of language transcripts. Eau Claire, WI: Thinking Publications.

Reed, V. A. (2005). An introduction to children with language disorders (3rd ed.). Boston, MA: Pearson/Allyn and Bacon.

Santrock, J. W. (1996). Child development (7th ed.). Madison, WI: Brown \& Benchmark Publishers.

Selman, R. L., Beardslee, W., Schultz, L. H., Krupa, M., \& Podorefsky, D. (1986). Assessing adolescent interpersonal negotiation strategies: toward the integration of structural and functional models. Developmental Psychology, 22(4), 450-459.

Suchithra, M. G., \& Karanth, P. (2007). Linguistic profile test-normative data 
for children in grades VI to X (11+ years - 15 years). All India Institute of Speech and Hearing, 26, 68-71.

Van Den Bos, W., \& Hertwig, R. (2017). Adolescents display distinctive tolerance to ambiguity and to uncertainty during risky decision making. Scientific Reports, 7, 40962.

Vieiro, P., \& Garcia-Madruga, J. A. (1997). An analysis of story comprehension through spoken and written summaries in school-age children. Reading and Writing, 9(1), 41-53.

Warner, J. (2002). Communication effectiveness profile. Amherst, MA: HRD Press.
Wiig, E. H., \& Secord, W. (1989). Test of Language Competence (TLC): expanded edition. San Antonio, TX: Psychological Corporation.

Wiig, E. H., Semel, E., \& Secord, W. A. (2013). Clinical Evaluation of Language Fundamentals-fifth edition (CELF-5). Bloomington, MN: Pearson/ PsychCorp.

Young, E. C., Diehl, J. J., Morris, D., Hyman, S. L., \& Bennetto, L. (2005). The use of two language tests to identify pragmatic language problems in children with autism spectrum disorders. Language, Speech, and Hearing Services in Schools, 36(1), 62-72. 
Appendix 1. Scoring guidelines for context related parameters

Scoring guidelines for context related parameters for visual scenes (1-6)

\begin{tabular}{|c|c|c|c|c|c|c|}
\hline & \multicolumn{6}{|c|}{ Visual scene } \\
\hline & 1 & 2 & 3 & 4 & 5 & 6 \\
\hline PCS & Library & Park & Study room/Room & Classroom/School & Living room/House & Clinic/Hospital \\
\hline Total PCS score & 1 & 1 & 1 & 1 & 1 & 1 \\
\hline \multirow[t]{2}{*}{ PCE } & $\begin{array}{l}\text { A girl talking loudly to } \\
\text { a boy (1) } \\
\text { Two girls who appear } \\
\text { to be unhappy are } \\
\text { watching the girl } \\
\text { who is talking (1) }\end{array}$ & $\begin{array}{l}\text { The girl is warning the } \\
\text { boy not to step on } \\
\text { the puddle (1) }\end{array}$ & $\begin{array}{l}\text { The teacher is angry } \\
\text { with the boy/student } \\
\text { for not being able to } \\
\text { finish his class/ } \\
\text { homework, and the } \\
\text { boy is upset and ap- } \\
\text { pears to be worried } \\
\text { about it (1) }\end{array}$ & $\begin{array}{l}\text { The boy is talking to the } \\
\text { girl in the classroom, } \\
\text { so the teacher is asking } \\
\text { the children to be quiet. } \\
\text { Another boy is sitting } \\
\text { in the corner of the } \\
\text { class (1) }\end{array}$ & $\begin{array}{l}\text { The parents are talking } \\
\text { and having a heated } \\
\text { discussion with one } \\
\text { another, and the son is } \\
\text { hiding and overhearing } \\
\text { their conversation (1) }\end{array}$ & $\begin{array}{l}\text { The boy/ patient appears } \\
\text { to have a stomach up- } \\
\text { set and is worried } \\
\text { about his problem. The } \\
\text { doctor appears to be } \\
\text { listening to the boy/ } \\
\text { patient while also hav- } \\
\text { ing an empathetic look } \\
\text { on his face (1) }\end{array}$ \\
\hline & $\begin{array}{l}\text { Keywords: library, chil- } \\
\text { dren, girls, convers- } \\
\text { ing, upset }\end{array}$ & $\begin{array}{l}\text { Keywords: children, } \\
\text { garden, water, pud- } \\
\text { dle, warn, step, girl, } \\
\text { boy }\end{array}$ & $\frac{\text { Keywords: boy, upset, }}{\text { worried, angry, work }}$ & $\begin{array}{l}\text { Keywords: children, sit- } \\
\text { ting, talking, disturbing, } \\
\text { teacher, standing, class }\end{array}$ & $\begin{array}{l}\text { Keywords: parents, child, } \\
\text { boy, overhear, conver- } \\
\text { sation, hide, sofa }\end{array}$ & $\begin{array}{l}\text { Keywords: boy, stomach } \\
\text { upset, worried, sad, } \\
\text { pain, doctor }\end{array}$ \\
\hline Total PCE score & 2 & 1 & 1 & 1 & 1 & 1 \\
\hline AN & $\begin{array}{l}3 \text { girls (3) } \\
1 \text { boy (1) }\end{array}$ & $\begin{array}{l}1 \text { girl (1) } \\
1 \text { boy (1) }\end{array}$ & $\begin{array}{l}1 \text { woman (1) } \\
1 \text { boy (1) }\end{array}$ & $\begin{array}{c}1 \text { woman (1) } \\
2 \text { boys (2) } \\
1 \text { girl (1) }\end{array}$ & $\begin{array}{c}1 \text { man (1) } \\
1 \text { woman (1) } \\
1 \text { boy (1) }\end{array}$ & $\begin{array}{l}1 \operatorname{man}(1) \\
1 \operatorname{boy}(1)\end{array}$ \\
\hline Total AN score & 4 & 2 & 2 & 4 & 3 & 2 \\
\hline AR & Friends/Classmates (1) & Friends/Siblings (1) & Teacher and student (1) & Teacher and students (1) & Parents and child (1) & Patient-doctor (1) \\
\hline Total AR score & 1 & 1 & 1 & 2 & 2 & 1 \\
\hline AM & $\begin{array}{l}\text { Excited/happy (1) } \\
\text { Sad/unhappy (1) }\end{array}$ & Surprised/startled (1) & $\begin{array}{c}\text { Angry/upset (1) } \\
\text { Worried (1) }\end{array}$ & Annoyed (1) & Anxious (1) & Anxious (1) \\
\hline Total AM score & 2 & 1 & 2 & 1 & 1 & 1 \\
\hline Total context score & 10 & 6 & 7 & 9 & 8 & 6 \\
\hline
\end{tabular}

PCS = physical context-setting; $P C E=$ physical context-event; $A R=$ audience relationship; $A N=$ audience number; $A M=$ audience mood; $C T=$ context total. 
Appendix 1. Continued

Scoring guidelines for context related parameters for visual scenes (7-12)

\begin{tabular}{|c|c|c|c|c|c|c|}
\hline & \multicolumn{6}{|c|}{ Visual scene } \\
\hline & 7 & 8 & 9 & 10 & 11 & 12 \\
\hline PCS & Playing room/Room & Leisure room/Classroom & Picture room/Room & Painting room/Room & Clock shop/Shop & Hall/House \\
\hline Total PCS score & 1 & 1 & 1 & 1 & 1 & 1 \\
\hline \multirow[t]{2}{*}{ PCE } & $\begin{array}{l}\text { Three friends/children } \\
\text { are playing carom } \\
\text { board. There is a boy } \\
\text { who is passing by, } \\
\text { hence the girl is calling } \\
\text { out to him and request- } \\
\text { ing him to join them to } \\
\text { play caroms (1) }\end{array}$ & $\begin{array}{l}\text { The girl wants to draw a } \\
\text { picture on the paper. } \\
\text { She doesn't have any } \\
\text { crayons with her, so } \\
\text { she decides to request } \\
\text { her friend to borrow } \\
\text { some crayons (1) }\end{array}$ & $\begin{array}{l}\text { The girl has climbed up } \\
\text { the ladder and is pin- } \\
\text { ning pictures on the } \\
\text { wall. She runs out of } \\
\text { pins, hence she calls } \\
\text { out to her friend/ } \\
\text { brother and asks his } \\
\text { help to get some pins } \\
\text { so that she can pin the } \\
\text { pictures on the wall (1) }\end{array}$ & $\begin{array}{l}\text { The boy painted a pic- } \\
\text { ture, which the girl } \\
\text { did not like, so the } \\
\text { girl is telling the boy } \\
\text { that the painting is } \\
\text { not good (1) }\end{array}$ & $\begin{array}{l}\text { The man had earlier pur- } \\
\text { chased a clock from } \\
\text { the shop. As the clock } \\
\text { broke, he re-visited } \\
\text { the shop and is asking } \\
\text { the owner to fix or re- } \\
\text { place his clock (1) }\end{array}$ & $\begin{array}{l}\text { The mother and daugh- } \\
\text { ter are sitting on the } \\
\text { sofa. The daughter ap- } \\
\text { pears to be worried } \\
\text { and depressed and the } \\
\text { mother is trying to } \\
\text { help and speak to her } \\
\text { and give her emotional } \\
\text { support (1) }\end{array}$ \\
\hline & $\begin{array}{l}\text { Keywords: four, children, } \\
\text { room, carom, playing, } \\
\text { game, girl, boy }\end{array}$ & $\begin{array}{l}\text { Keywords: children, } \\
\text { room, colour, borrow, } \\
\text { crayons, picture }\end{array}$ & $\begin{array}{l}\text { Keywords: girl, boy, lad- } \\
\text { der, climb, pinning, } \\
\text { pins, pictures, wall }\end{array}$ & $\begin{array}{l}\text { Keywords: boy, paint, } \\
\text { picture, girl, painting, } \\
\text { sad, hurt }\end{array}$ & $\begin{array}{l}\text { Keywords: man, pur- } \\
\text { chased, clock, shop, } \\
\text { broke, owner, fix, re- } \\
\text { place }\end{array}$ & $\begin{array}{l}\text { Keywords: mother, } \\
\text { daughter, sitting, sofa, } \\
\text { worried, help, speak, } \\
\text { support }\end{array}$ \\
\hline Total PCE score & 1 & 1 & 1 & 1 & 1 & 1 \\
\hline AN & $\begin{array}{l}2 \text { boys (2) } \\
2 \text { girls (2) }\end{array}$ & $\begin{array}{l}1 \text { girl (1) } \\
1 \text { boy (1) }\end{array}$ & $\begin{array}{l}1 \text { girl (1) } \\
1 \text { boy (1) }\end{array}$ & $\begin{array}{l}1 \text { girl (1) } \\
1 \text { boy (1) }\end{array}$ & 2 men (2) & 2 women (2) \\
\hline Total AN score & 4 & 2 & 2 & 2 & 2 & 2 \\
\hline $\mathrm{AR}$ & $\begin{array}{l}\text { Friends/Cousins/ } \\
\text { Siblings (1) }\end{array}$ & Friends/Siblings (1) & $\begin{array}{l}\text { Friends/Students/ } \\
\text { Siblings (1) }\end{array}$ & $\begin{array}{l}\text { Friends/Students/ } \\
\text { Siblings (1) }\end{array}$ & Client-customer (1) & Mother-daughter (1) \\
\hline Total AR score & 1 & 1 & 1 & 1 & 1 & 1 \\
\hline AM & Happy/excited (1) & Calm/neutral (1) & Calm/neutral (1) & Sad/unhappy (1) & Anxious/sad/worried (1) & $\begin{array}{l}\text { Console/worried/ } \\
\text { anxious (1) }\end{array}$ \\
\hline Total AM score & 1 & 1 & 1 & 1 & 1 & 1 \\
\hline Total context score & 8 & 6 & 6 & 6 & 6 & 6 \\
\hline
\end{tabular}

PCS = physical context-setting; $P C E=$ physical context-event; $A R=$ audience relationship; $A N=$ audience number; $A M=$ audience mood; $C T=$ context total.

(Continued to the next page) 
Appendix 1. Continued

Scoring guidelines for context related parameters for visual scenes (13-18)

\begin{tabular}{|c|c|c|c|c|c|c|}
\hline & \multicolumn{6}{|c|}{ Visual scene } \\
\hline & 13 & 14 & 15 & 16 & 17 & 18 \\
\hline PCS & Stadium & Living room/House & Discussion room/Room & House & Garden/Park & Restaurant/Hotel \\
\hline Total PCS score & 1 & 1 & 1 & 1 & 1 & 1 \\
\hline \multirow[t]{2}{*}{ PCE } & $\begin{array}{l}\text { Two girls are in the cor- } \\
\text { ner, and they appear to } \\
\text { be talking bad and fun- } \\
\text { ny things about another } \\
\text { girl who is sitting a lit- } \\
\text { tle distant. She appears } \\
\text { to be sad and upset be- } \\
\text { cause the other two } \\
\text { girls are making fun of } \\
\text { her and talking ill of her } \\
\text { (1) }\end{array}$ & $\begin{array}{l}\text { The picture appears as the } \\
\text { boy has done some seri- } \\
\text { ous mischief and the fa- } \\
\text { ther is asking him what } \\
\text { has happened and why } \\
\text { he was mischievous. } \\
\text { Also, the boy appears to } \\
\text { be sad and guilty about } \\
\text { what he has done. His } \\
\text { sister/mother standing } \\
\text { in the background ap- } \\
\text { pears to be angry and } \\
\text { upset with him regard- } \\
\text { ing the same (1) }\end{array}$ & $\begin{array}{l}\text { A group of five mem- } \\
\text { bers is sitting and } \\
\text { discussing some mat- } \\
\text { ter (Can be anything- } \\
\text { college group, asso- } \\
\text { ciation, friends) (1) }\end{array}$ & $\begin{array}{l}\text { The mother is convinc- } \\
\text { ing her daughter that } \\
\text { she needs to listen to } \\
\text { her, but the daughter } \\
\text { demonstrates temper } \\
\text { tantrums and does } \\
\text { not want to listen to } \\
\text { her (1) }\end{array}$ & $\begin{array}{l}\text { The children/siblings } \\
\text { were playing in the } \\
\text { garden. While play- } \\
\text { ing, the boy got hurt, } \\
\text { so the girl was apolo- } \\
\text { gising to him (1) }\end{array}$ & $\begin{array}{l}\text { The woman has come } \\
\text { to the restaurant and } \\
\text { ordered a dish for } \\
\text { herself. The waiter } \\
\text { got her a very hot/ } \\
\text { bad dish, so she ap- } \\
\text { pears to be scolding } \\
\text { the waiter (1) }\end{array}$ \\
\hline & $\begin{array}{l}\text { Keywords: girls, bad, fun- } \\
\text { ny, upset, sitting }\end{array}$ & $\begin{array}{l}\text { Keywords: boy, mischief, } \\
\text { father, sad, guilty, sister, } \\
\text { standing, sitting, angry }\end{array}$ & $\begin{array}{l}\text { Keywords: group, five, } \\
\text { discussion, members }\end{array}$ & $\begin{array}{l}\text { Keywords: mother, } \\
\text { daughter, listen, tem- } \\
\text { per tantrums }\end{array}$ & $\begin{array}{l}\text { Keywords: children, } \\
\text { garden, boy, hurt, girl, } \\
\text { apologise, sad }\end{array}$ & $\begin{array}{l}\text { Keywords: woman, res- } \\
\text { taurant, dish, waiter, } \\
\text { hot, bad, scolding }\end{array}$ \\
\hline Total PCE score & 1 & 1 & 1 & 1 & 1 & 1 \\
\hline AN & 3 girls (3) & $\begin{array}{c}1 \mathrm{girl} / \operatorname{woman}(1) \\
1 \text { boy (1) } \\
1 \text { man (1) }\end{array}$ & $\begin{array}{c}3 \text { men (3) } \\
2 \text { women (2) }\end{array}$ & $\begin{array}{l}1 \text { woman (1) } \\
1 \mathrm{girl}(1)\end{array}$ & $\begin{array}{l}1 \text { boy (1) } \\
1 \text { girl (1) }\end{array}$ & $\begin{array}{c}1 \text { man (1) } \\
1 \text { woman (1) }\end{array}$ \\
\hline Total AN score & 3 & 3 & 5 & 2 & 2 & 2 \\
\hline$A R$ & Students/Friends (1) & $\begin{array}{l}\text { Parent-children, } \\
\text { Siblings (2) }\end{array}$ & $\begin{array}{c}\text { Friends/Colleagues/ } \\
\text { Members (1) }\end{array}$ & Mother-daughter (1) & Friends/Siblings (1) & Waiter-customer (1) \\
\hline Total AR score & 1 & 2 & 1 & 1 & 1 & 1 \\
\hline AM & Upset/sad(1) & $\begin{array}{l}\text { Calm/console (1) } \\
\text { Angry (1) } \\
\text { Guilty (1) }\end{array}$ & Calm (1) & Upset/convince (1) & Upset/apologize (1) & Upset/apologize (1) \\
\hline Total AN score & 1 & 3 & 1 & 1 & 1 & 1 \\
\hline Total context score & 7 & 10 & 9 & 6 & 6 & 6 \\
\hline
\end{tabular}

$\mathrm{PCS}=$ physical context-setting; $\mathrm{PCE}=$ physical context-event; $\mathrm{AR}=$ audience relationship; $\mathrm{AN}=$ audience number; $\mathrm{AM}=$ audience mood; $C T=$ context total.

(Continued to the next page) 


\section{Appendix 1. Continued}

Summary of scores of visual scenes (1-18)

\begin{tabular}{lc}
\hline Visual scene & Total context score \\
\hline 1 & 10 \\
2 & 6 \\
3 & 7 \\
4 & 9 \\
5 & 8 \\
6 & 6 \\
7 & 8 \\
8 & 6 \\
9 & 6 \\
10 & 6 \\
11 & 6 \\
12 & 6 \\
13 & 7 \\
14 & 10 \\
15 & 9 \\
16 & 6 \\
17 & 6 \\
18 & 6 \\
\hline
\end{tabular}




\title{
국문초록
}

\section{문맥 그림 자극을 사용한 10-16세 인도 청소년의 화용 언어능력 평가}

\author{
Larisa Vaz ${ }^{1,2} \cdot$ Sudhin Karuppali
}

'Kasturba Medical College, ${ }^{2}$ Manipal Academy of Higher Education

배경 및 목적: 청소년의 화용언어 평가는 이들이 주로 접하는 학업이나 기타 다른 의사소통 맥락을 사용한다. 지금까지 인도에서는 화 용언어 평가에 대한 관심이 적었기에 본 연구는 독창적인 시각자료를 사용하여 정상발달을 보이는 청소년의 맥락 관련 화용능력 프로 파일을 제공하고자 하였다. 방법: 본 연구의 참여자는 10-16세 청소년이었으며 1년 간격의 여섯 연령집단으로 구분되었다. 본 연구에서 는 물리적 상황 맥락(PCS), 물리적 사건 맥락(PCE), 청자 관계(AR), 청자 수(AN), 청자 감정상태(AM), 종합적 맥락(CT) 등으로 맥락 관 련 변수를 측정하였다. 본 연구는 세 단계로 실시되었다. 첫 단계는 자극 개발 단계(자극 준비, 내용 타당성, 예비연구)이었으며, 두 번째 단계는 과제실행 단계, 세 번째 단계는 자료 및 통계분석 단계이었다. 결과: 본 연구에서는 PCS, PCE, AR, AN, AM, CT 점수를 연령에 따라 비교하였다. 크루스칼 왈리스 테스트 결과, 총 여섯 변수 모두에서 연령에 따른 차이가 통계적으로 유의하였다 $(p<.05)$. 만-휘트니 테스트 결과, 일부 연령집단에서는 통계적으로 유의한 차이가 관찰되지 않았으나( $p>.05)$ 인지발달에 따른 일부 연령집단(10-11세, 12-14세, 15 세)에서는 통계적으로 유의한 차이가 관찰되었다 $(p<.05)$. 논의 및 결론: 본 연구는 인도 아동의 정상 화용발달 단계를 이해 하는 데 도움이 될 수 있는 새로운 평가도구를 제시하였으며 이를 통해 언어발달장애가 있는 청소년 평가에 도움을 줄 수 있을 것이다.

핵심어: 청소년, 평가, 문맥, 그림, 화용

\section{ORCID}

Larisa Vaz (https://orcid.org/0000-0002-0708-584X); Sudhin Karuppali (https://orcid.org/0000-0003-2955-8107) 